\title{
Are Government Bonds Net Wealth? Some Empirical Evidence
}

\author{
Tito Belchior Silva Moreira ${ }^{1}$, Geraldo da Silva e Souza ${ }^{2}$, Fernando Antônio Ribeiro Soares ${ }^{3}$ \\ ${ }^{1}$ Department of Economics, Catholic University of Brasília, Brasília, Brazil \\ ${ }^{2}$ Department of Statistics, University of Brasilia, Brasília, Brazil \\ ${ }^{3}$ Brazilian Ministry of Defense, Brasília, Brazil \\ E-mail: tito@pos.ucb.br, geraldosouza@unb.br,fernando.a.r.soares@gmail.com \\ Received March 3, 2011; revised April 25, 2011; accepted May 5, 2011
}

\begin{abstract}
This paper aims to investigate the impact of government debt on economic growth for a balanced panel of G7 countries over the period 1990-2008. We found empirical evidence that Ricardian Equivalence does not holds in general. The analysis indicates that only Germany shows a negative association between public debt and economic growth. The US and France show Ricardian equivalence and UK, Japan, Italy and Canada show a positive association.
\end{abstract}

Keywords: Public Debt, Economic Growth, Ricardian Equivalence

\section{Introduction}

Roughly fifty years ago, [1] wrote a note presenting a case for the "classic view" that bond financing of public expenditures - unlike pay-as-you-go financing - places a burden on future generations. Reference [2], dealing with an intimately related issue, cast a model in which government debt does not affect the perceived net wealth of households [3]. David Ricardo pointed out that they might conceivably treat the future taxes servicing the government debt as exactly offsetting it. Reference [2] has shown that maximizing households will actually do so if they accurately anticipate future taxes, if they face perfect capital markets, and if they have effectively infinite horizons. The Ricardian Equivalence Proposition (REP), clearly stated in [2], is said to hold if households do treat future servicing taxes as an exact offset to the government debt [4]. Both publications stimulated much debate about the rule of government bonds in macroeconomics.

The empirical evidence for REP is usually investigated following two approaches. The first seeks effects of government deficits on interest rates, while the second analyses the impact of a fiscal policy variable, e.g. public debt, on the behavior of an aggregated macroeconomic variable, which could be either consumption or savings, for example [5]. In this sense, the private agents perceive a fraction of government bonds as a net wealth.
In the same line of the second approach presented above, it is possible to test the impact of public debt on economic growth. Araujo e Martins model (Reference [6]), a straightforward extension of [7-9], Martins (1980, 1994, 1995), relying on Samuelson's pioneering OLG model [10], is the proper framework for the analysis. Based on [6], we investigate a possible association between public debt and economic growth, in the context of the AK model. We note here that [6] concluded that an increase in government debt negatively affects the rate of growth of the capital stock and, consequently, negatively affects the economic growth.

However, there is another explanation for the positive association between public debt and economic growth. The public investment may be complementary to private investment in so far that, by generating positive externalities, it creates favorable conditions for the latter. In this case, public investment can have a complementary effect (crowding-in) with respect to private investment, especially when it is made in the areas of infrastructure and the provision of public goods. The so-called supply-side impact estimates the effect of public investment on total factor productivity. One of the first studies in this area was that of [11], followed by [12-14]. It may be noted that [15] has developed a model in line with the "new growth theory". He shows that public investment has a strong impact on the marginal productivity of private capital and labor. This line of research originated a 
number of empirical studies, such as, [16-20].

\section{Araujo and Martins Model ${ }^{1}$}

Reference [6] demonstrate that sustained long-run growth is possible in a one-sector overlapping-generations framework assuming a convex technology, without income redistribution from old to the young supported by income taxation and without "pure" altruism à la [2]. Considering an AK production function, and under the assumption that the agent's utility function embodies an absolute bequest motive, the authors derive one clear policy implication from the model: an increase in government debt negatively affects the rate of growth of the capital stock as:

$$
\frac{K_{t}-K_{t-1}}{K_{t-1}}=\frac{\delta A-1}{1+\delta}-\frac{B_{t} / K_{t-1}}{(1+A)(1+\delta)}
$$

where $K_{t}$ is the stock of capital at the beginning of time $t$, $B_{t}$ is the outstanding stock of bonds at the beginning of period $t, A$ represents the technology and the coefficient $\delta$ denotes the agent's preferences. This equation shows the endogenous rate of growth of the capital stock. The flow of governmental debt financing as a proportion of the pre-exiting stock of capital actually negatively affects the rate of capital accumulation.

Substituting $K_{t}=Y_{t} / A$ into Equation (1) we obtain:

$$
\frac{Y_{t}-Y_{t-1}}{Y_{t-1}}=\beta_{0}-\beta_{1} \frac{B_{t}}{Y_{t-1}}
$$

where $\beta_{0}=\frac{\delta A-1}{1+\delta}$ and $\beta_{1}=\frac{A}{(1+A)(1+\delta)}$.

Equation (2) has the observational representation:

$$
\tilde{Y}_{t}=\beta_{0}-\beta_{1} b_{t}+\eta_{t}
$$

where $\tilde{Y}_{t}=\frac{Y_{t}-Y_{t-1}}{Y_{t-1}}, b_{t}=\frac{B_{t}}{Y_{t-1}}$ and $\eta_{t}$ is a stochastic error. We will use this formulation in our statistical exercise.

\section{Empirical Results}

We use annual data from 1990 to 2008 to assess the Ricardian equivalence and the nature of the association between government debt and economic growth for the G7 countries (Canada, France, Germany, Italy, Japan, United Kingston and United States).

As a proxy for economic growth $(\tilde{Y})$ we use the annual percent change of Gross Domestic Product (GDP) at constant prices and for the ratio public debt/GDP $\left(b_{t}\right)$ we

${ }^{1}$ Reference [6]. use the general government net debt as a percent of GDP. ${ }^{2}$ The source of data is the International Monetary Fund, World Economic Outlook Database, April 2008. We use dummy variables to differentiate the countries. The basis is US.

The dynamic panel method of analysis employed here follows [22] and [23]. Table 1 shows the estimation results for the basic model:

$$
\tilde{Y}_{i t}=\beta_{0}+\beta_{1} \tilde{Y}_{i, t-1}+\beta_{2} \tilde{Y}_{i, t-2}+\beta_{3} b_{i t}+\beta_{4} b_{i, t-1}+\eta_{i}+\varepsilon_{i t}
$$

where $\eta_{i}$ is a random effect for country $i$ and $\varepsilon_{i t}$ is an error component not showing serial correlation of second order. The test for the presence of second order autocorrelation has a p-value of $68 \%$ and the model seems adequate.

All variables are significant at the $1 \%$ level. We note that in the long run the net effect of $b_{t}$ and $b_{t-1}$ is negative and statistically significant ( $\mathrm{p}$-value $<0.1 \%$ ), as expected. In this sense, the increment of the ratio public debt/GDP results in a reduction of the economic growth.

Now we consider the model:

$$
\begin{aligned}
& \tilde{Y}_{i t}=\beta_{0}+\beta_{1} \tilde{Y}_{i, t-1}+\beta_{2} \tilde{Y}_{i, t-2}+\beta_{3} b_{i t}+\beta_{4} b_{i, t-1}+\sum_{i=1}^{6} \delta_{i} D_{i} \\
& +\sum_{i=1}^{6} \alpha_{i} D_{i} b_{i t}+\sum_{i=1}^{6} \gamma_{i} D_{i} b_{i, t-1}+\sum_{i=1}^{6} \varphi_{i} D_{i} b_{i, t-2}+\eta_{i}+\varepsilon_{i t}
\end{aligned}
$$

which assumes different intercepts and net debt coefficients for each country with a common dynamic economic growth component structure.

Table 2 shows the estimation results for Model (5). The Hausman specification test provides evidence of a superior fit of Model (5) relative to Model (4). The test for the presence of second order autocorrelation has a p-value of $37 \%$ and the moment conditions seem adequate.

In the long run the net effect of $b_{t}, b_{t-1}$ and $b_{t-2}$ is negative and statistically significant for some countries and not for others. Table $\mathbf{3}$ shows the results.

France and the US show Ricardian equivalence. Only Germany has a long run negative net effect of the ratio debt/GDP in accordance with the model of [6]. In this

Table 1. Estimation of Equation (4).

\begin{tabular}{cccc}
\hline Variables & Coefficients & $\begin{array}{c}\text { Robust } \\
\text { Standard Error }\end{array}$ & p-values \\
\hline$\tilde{Y}_{t-1}$ & 0.255 & 0.077 & 0.001 \\
$\tilde{Y}_{t-2}$ & -0.232 & 0.044 & $<0.001$ \\
$b_{t}$ & -0.164 & 0.041 & $<0.001$ \\
$b_{t-1}$ & 0.162 & 0.042 & $<0.001$ \\
Constant & 2.319 & 0.486 & $<0.001$ \\
\hline
\end{tabular}

${ }^{2}$ We also used the government gross debt as a percent of GDP. The results were similar. 
Table 2. Estimation of Equation (5).

\begin{tabular}{|c|c|c|c|}
\hline Variables & Coefficients & $\begin{array}{c}\text { Robust } \\
\text { Standard Error }\end{array}$ & p-values \\
\hline$\tilde{Y}_{t-1}$ & 0.006 & 0.085 & 0.995 \\
\hline$\tilde{Y}_{t-2}$ & -0.312 & 0.078 & $<0.001$ \\
\hline$b_{t}$ & -0.597 & 0.045 & $<0.001$ \\
\hline$b_{t-1}$ & 0.916 & 0.063 & $<0.001$ \\
\hline$b_{t-2}$ & -0.328 & 0.033 & $<0.001$ \\
\hline$D_{1} b_{1 t}$ & 0.382 & 0.036 & $<0.001$ \\
\hline$D_{1} b_{1, t-1}$ & -0.719 & 0.072 & $<0.001$ \\
\hline$D_{1} b_{1, t-2}$ & 0.398 & 0.047 & $<0.001$ \\
\hline$D_{2} b_{2, t}$ & 0.243 & 0.018 & $<0.001$ \\
\hline$D_{2} b_{2, t-1}$ & -0.522 & 0.044 & $<0.001$ \\
\hline$D_{2} b_{2, t-2}$ & 0.284 & 0.029 & $<0.001$ \\
\hline$D_{3} b_{3, t}$ & 0.310 & 0.032 & $<0.001$ \\
\hline$D_{3} b_{3, t-1}$ & -0.943 & 0.081 & $<0.001$ \\
\hline$D_{3} b_{3, t-2}$ & 0.511 & 0.053 & $<0.001$ \\
\hline$D_{4} b_{4, t}$ & 0.408 & 0.058 & $<0.001$ \\
\hline$D_{4} b_{4, t-1}$ & -0.568 & 0.096 & $<0.001$ \\
\hline$D_{4} b_{4, t-2}$ & 0.216 & 0.052 & $<0.001$ \\
\hline$D_{5} b_{5, t}$ & 0.371 & 0.029 & $<0.001$ \\
\hline$D_{5} b_{5, t-1}$ & -0.793 & 0.080 & $<0.001$ \\
\hline$D_{5} b_{5, t-2}$ & 0.441 & 0.052 & $<0.001$ \\
\hline$D_{6} b_{6, t}$ & 0.659 & 0.070 & $<0.001$ \\
\hline$D_{6} b_{6, t-1}$ & -0.848 & 0.078 & $<0.001$ \\
\hline$D_{6} b_{6, t-2}$ & 0.314 & 0.040 & $<0.001$ \\
\hline$D_{1}$ & -2.856 & 1.480 & 0.054 \\
\hline$D_{2}$ & -0.127 & 1.823 & 0.944 \\
\hline$D_{3}$ & 4.939 & 2.050 & 0.016 \\
\hline$D_{4}$ & -7.213 & 2.096 & 0.001 \\
\hline$D_{5}$ & -0.541 & 1.640 & 0.742 \\
\hline$D_{6}$ & -4.133 & 1.610 & 0.010 \\
\hline Constant & 3.820 & 1.197 & 0.001 \\
\hline
\end{tabular}

context, a government debt crowd-out productive investment as it competes with capital for individuals' non-consumed output. Canada, Italy, Japan and UK show positive statistically significant long run net effects.
Table 3. Intercepts and public debt coefficients for Model (5).

\begin{tabular}{llllll}
\hline & \multicolumn{2}{l}{ Coefficients } & \multicolumn{2}{l}{ Long run net effect } \\
\hline Countries & Constant & $b_{t}$ & $b_{t-1}$ & $b_{t-2}$ & p-value $\left.{ }^{*}\right)$ \\
Canada (1) & 0.96 & -0.22 & 0.20 & 0.07 & $<0.001$ \\
France (2) & 3.82 & -0.36 & 0.40 & -0.05 & 0.657 \\
Germany (3) & 8.76 & -0.29 & -0.02 & 0.18 & $<0.001$ \\
Italy (4) & -3.39 & -0.19 & 0.35 & -0.11 & $<0.001$ \\
Japan (5) & 3.82 & -0.23 & 0.13 & 0.11 & 0.016 \\
UK (6) & -7.95 & 0.06 & 0.07 & -0.02 & $<0.001$ \\
US (7) & 3.82 & -0.60 & 0.92 & -0.33 & 0.348 \\
\hline
\end{tabular}

$\left({ }^{*}\right)$ Wald test, $H_{0}: \alpha_{i}+\gamma_{i}+\varphi_{i}=0$.

\section{Conclusions}

The empirical results show that the economic growth is not independent of public debt and that the Ricardian Equivalence hypothesis is not generally valid. Indeed only the US and France show Ricardian Equivalence. Germany follows the model of Araujo and Martins [6] indicating that there is competition between public and private investment, so that the former "crowds-out" the latter.

The other countries of G7 show a positive association between public debt and economic growth. Theoretically the net effect should be negative. We point out two major reasons to explain positive empirical results for Canada, Italy, Japan and UK. Firstly is that Araujo and Martins model is valid only for closed economies and the IMF measurements of government debt comprises all government gross liabilities for both residents and non residents. Finally the theoretical model assumes the debt formed exclusively by treasures bill. A suggestion for further investigation involves an extension of Araujo and Martins model for an open economy. This line of research should take into account possible financial linkages among the countries that might transfer REP to the exchange rate.

\section{Reference}

[1] W. G. Bowen R. G. Davis and D. H. Kopf, "The Public Debt: a Burden on Future Generations?” American Economic Review, Vol. 50, 1960, pp. 701-706.

[2] R. J. Barro, “Are Government Bonds Net Wealth?” Journal of Political Economy, Vol. 91, 1974, pp. 10951117.

[3] M. A. C. Martins, "Theoretical Problems in the Thory of the Burden of the Debt," Instituto de Pesquisa Econômica Aplicada, Brasília, 1979. 
[4] P. Evans, "Consumers Are Not Ricardian: Evidence from Nineteen Countries,” Economic Inquiry, Vol. 31, 1993, pp. 534-548.

[5] P. C. Rodrigues, “The Ricardian Equivalence Proposition in OCDE Countries: Does Government Debt Wight Down Growth?” Ph.D. Thesis, School of Economics, University of Nottingham, Nottingham, 2006.

[6] J. T. Araujo and M. A. C. Martins, "Economic Growth with Finite Lifetimes,” Economics Letters, Vol. 62, 1999, pp. 377-381.

[7] M. A. C. Martins, "A Nominal Theory of the Nominal Rate of Interest and the Price Level,” Journal of Political Economy, Vol. 88, 1980, pp. 174-185.

[8] M. A. C. Martins, "Interest, Prices, and the Barsky-Summers Resolution of the Gibson Paradox under the Gold Standard System,” Revista Brasileira de Economia, Vol. 48, 1994, pp. 3-28.

[9] M. A. C. Martins, "Bonds, Interests and Capital Accumulation,” Revista Brasileira de Economia, Vol. 49, 1995, pp. 557-582.

[10] P. A. Samuelson, “An Exact Consumption-Loan Model of Interest with or without the Social Contrivance of Money,” Journal of Political Economy, Vol. 66, 1958, pp. 467-482.

[11] R. Ram, “Government Size and Economic Growth: A New Framework and Some Evidence from Cross-Section and Time-Series Data,” American Economic Review, Vol. 76, 1986, pp. 191-203.

[12] D. A. Aschauer, "It is Public Expenditure Productive," Journal of Monetary Economics, Vol. 23, 1989, pp. 177-200.

[13] D. A. Aschauer, "Public Investment and Productivity
Growth in the Group of Seven,” Journal of Economic Perspective, Vol. 13, 1989, pp. 17-25.

[14] D. A. Aschauer, "Does Public Capital Crowd Out Private Capital?” Journal of Monetary Economics, Vol. 24, 1989, pp. 171-188.

[15] R. J. Barro, "Government Spending in a Simple Model of Endogenous Growth,” Journal of Political Economy, Vol. 98, 1990, pp. S103-S125.

[16] W. Easterly and S. Rebelo, "Fiscal Policy and Economic Growth: An Empirical Investigation,” Journal of Monetary Economics, Vol. 32, 1993, pp. 417-458.

[17] D. Canning, M. Fay and R. Perotti, "Infrastructure and Growth,” In: M. Baldassarri, M. Baganeatto and E. S. Phelps, Eds., International Differences in Growth Rates: Market Globalization and Economic Areas, St. Martins Press, New York, 1994.

[18] B. Sanchez-Robles, "Infrastructure Investment and Growth: Some Empirical Evidence,” Contemporary Economic Policy, Vol. 16, 1998, pp. 98-108.

[19] D. Canning, D. and P. Pedroni. "Infrastructure and Long Run Economic Growth,” CAE Working Paper No. 99-09, Cronell University, Ithaca, 1999.

[20] B. O. Cruz and Joanílio R. Teixeira, “The Impact of Public Investment on Private Investment in Brazil: 19471990,” Cepal Review, Vol. 67, 1999, pp. 75-84.

[21] I. M. F., "World Economic Outlook Database,” 2008.

[22] M. Arellano and O. Bover, "Another Look at the Instrumental Variable Estimation of Error-Components Models,” Journal of Econometrics, Vol. 68, 1995, pp. 29-51.

[23] R. Blundell and S. Bond, "Initial Conditions and Moment Restrictions in Dynamic Panel-Data Models," Journal of Econometrics, Vol. 87, 1998, pp. 115-143. 